\title{
細菌多糖類の抗原性に関する研究
}

\author{
第 1 編 \\ Proteus X19 菌多糖類の精製に就にて \\ 岡山大学医学部公策街生学敉室（主任 : 大田原一祥教授） \\ 製攻生横 山衛
}

〔昭和 32 年 11 月 1 日受稿】

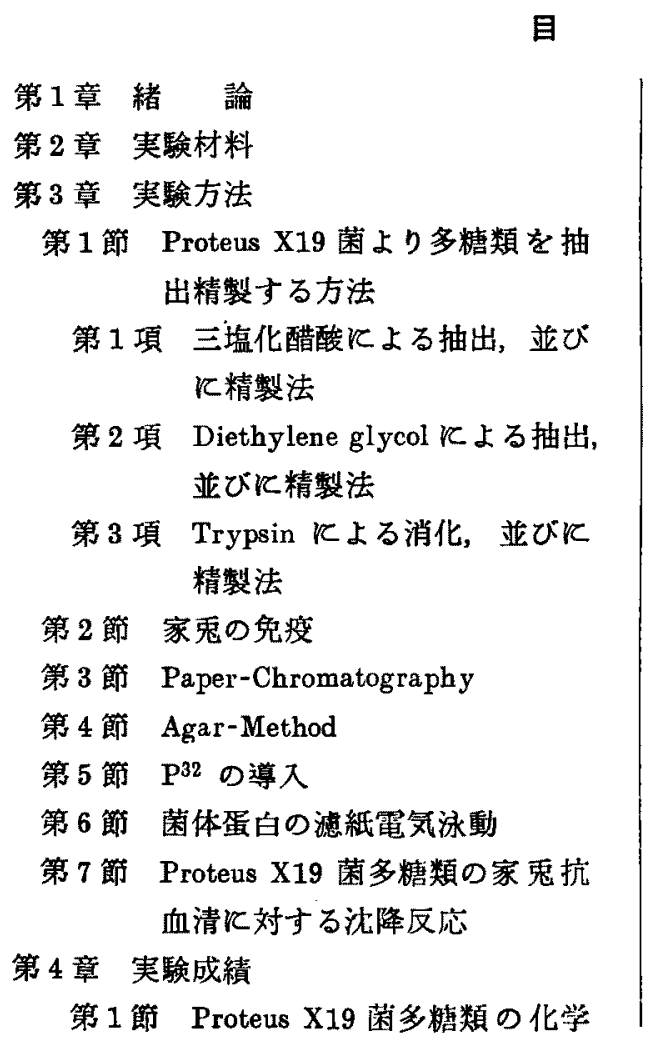

\section{第1章 緒論}

細菌多糖類の分離に関する研究は，1920年 Toenniessen (が莢膜を有する Friedländer 菌 より多糖類を分離してょり，急速に発達し， Landsteiner ${ }^{2)-5)}$, Avery ${ }^{6)-13) 20)-23), ~ H e i d e l b e r-~}$ ger $^{8) \cdot 18)}$, Goebel (6)18)-24), Sevag25) 等数多くの 研究が相次いで発表された。 これらの細菌多 糖類を分蜼する方法として，菌体を(1)酸又は
次

\section{的性状}

第 1 項 Biuret 反応及び Molisch 反応

第 2 項 Paper-Chromatography

第 3 項 Agar-Method

第 4 項 $\mathbf{P}^{32}$ の導入

第 5 項 菌体蛋白の滤紙電気泳動

第 2 節 三境化醋酸抽出法飞より抽出し た多糖類の抗 Proteus X19 菌家 鬼血清飞対与る沈降反応

第 3 節 Proteus X19 菌多糖類の抽出, 並びに消化成績

第 1 項 三塩化醋酸による抽出成績

第 2 項 Diethylene glycol とよる抽出 成績

第 3 項 Trypsin Kよる消化成績

第 4 項 各抽出（或は消化）法により 得たる多糖類の收量及び純度 比

㔍 5 染考 按

第 6 管 絬 諭

アルカリを以て処理する方法，(2) 硫酸銅， Fehling 液等の金属壏浴液を使用する方法， 及び (3) Chloroformin-Protein-Gel 等が用い られていたが，抗原としての多糖類は，強酸， アルカリ等に対して変性の危険があるために, 強酸，アルカリ或江熱処理は可及的に避くべ きであるとされていた。

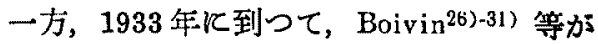
三塩化醌酸を用いて Paratyphus 菌より多糖 
類を分離してより，Gram 陰性菌多糖類，所 謂 Boivin type antigen の抽出法が著し々進步

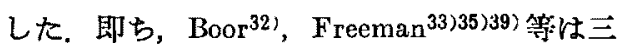

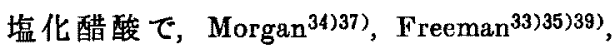
Henderson ${ }^{36) 37)}$ 等は Diethylene glycol を用 いて多糖類を抽出し, Topley ${ }^{37) 38), ~ R a i s t r i c k ~}$ 37)38)，Freeman ${ }^{33) 35) 39)}$ 等は Trypsin で菌体 を消化し多糖類を分離した。

これ等は，加熱除蛋白の操作が無い為飞多 糖類抗原の分離抽出に当り，其の変性を最小 限度に止めているのが特徵である.

又, Proteus X19 菌より多糖類を分雖する 方法としては，(1) Przesmycki40) の醋酸加 熱法，(2) Meise141) 等のアルカリ法及び酸 法, (3) Castaneda 42)-44) $の$ Antiformin 法, (4) Furth ${ }^{45)}$ 等の Antiformin 法及び Trypsin 消化法，(5) White ${ }^{46)}$ の Trypsin 消化法，(6) Bendich ${ }^{47)}$ 等の三塩化醋酸法及び Trypsin 消 化法，(7)黑屋 ${ }^{48)}$ 等の中性及び酸性加熱法，及 び(8)同本49) 等の諸法がある.

著者は Proteus X19 菌より多糖類を分離 するK当り，可及的変性の少い方法とし $\tau$, 三塩化醌酸法, Diethylene glycol 法及び Trypsin 消化法の 3 法を用い，之等の分離方 法，純度及び收量の此較検討並びに本多糖類 の化学的性状に関する実験を行い，興味ある 成緽を得たのでこつ報告する。

\section{第 2 章 実酫材料}

使用菌は岡山大学医学部微生物学教室保存 の Proteus X19 菌の分与を受けて之を使用 し、笑験動物としては体重約 $3,000 \mathrm{gm}$ 前後 の家鬼を用いた。

\section{第3章実酫方法}

\section{第1節 Proteus X19 菌より多糖類} を抽出精幣する方法

第 1 項 三塩化酷酸による抽出，並び 飞精製法

Proteus X19 茵より三塭化醌酸によつて 多糖類を抽出するには，第 1 表に示す如く，

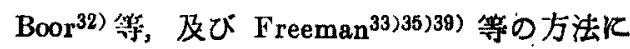

第1表 ProteusX19 菌多糖類の三塩化 醋酸による抽出順序

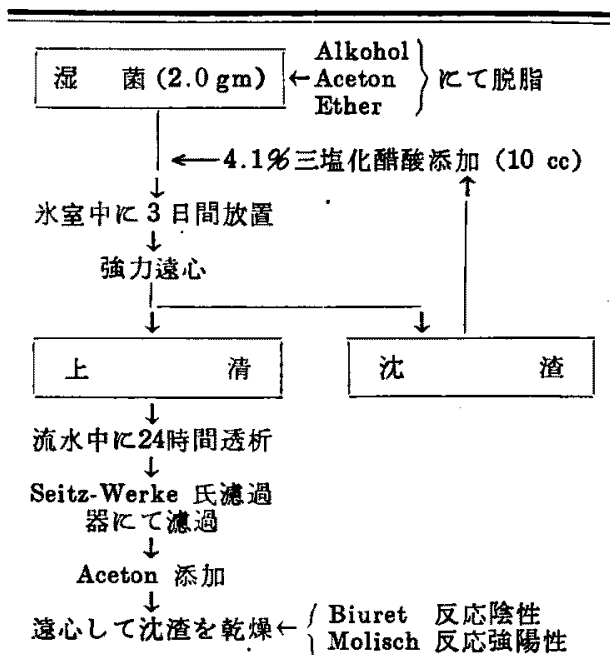

準じて下記の如く行つた.

即ち, 前記 Proteus X19 菌を Kolle 氏瓶 普通寒天平板培美基を用いて24時間培養し， これを生理的食塩水で洗滌して菌浮游液を作 り，この菌浮游液を遠心して集菌した湿菌塊 を, Alkohol, Aceton, 及び Etherで順次飞洗 滌して脱脂した。〔脱脂湿菌 $2.0 \mathrm{gm}$ 〕

次に，この脱脂湿菌塊を乳針を用いて磨碎 乙，これと $4.1 \%$ 三塩化醋酸 $10 \mathrm{cc}$ を加克て, 3 日間氷室中に放置した後強力に遠心し，そ の上清をとロファン膜に包み流水中に24洔間 透析した.（沈渣は再び三塩化醋酸 $10 \mathrm{cc}$ を加 之第 2 回目の抽出を同滕操作で行 3. 以下同 様）透析終了後，これを精製する目的で， Seitz-Werke 氏渾過器 (以後 S 氏滤過器と略 称する)を用いて滤過した。此の滤液に Acetonを加えて生じた白色沈澱を遠心して集 めた後, 減生乾燥して保存した。

この様にして本菌塊に対し連続して 5 回抽 出を行つた。

第2 項 Diethylene glycol Kよる抽出， 並びに精製法

Diethlene glycol Kよる抽出については,

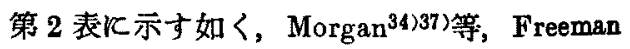

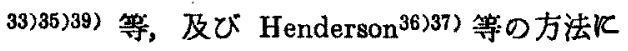
华して下記の如く行つた. 即ち, Proteus 
第 2 表 Proteus X19 菌多糖類の Diethylene glycol 飞よる抽出順序

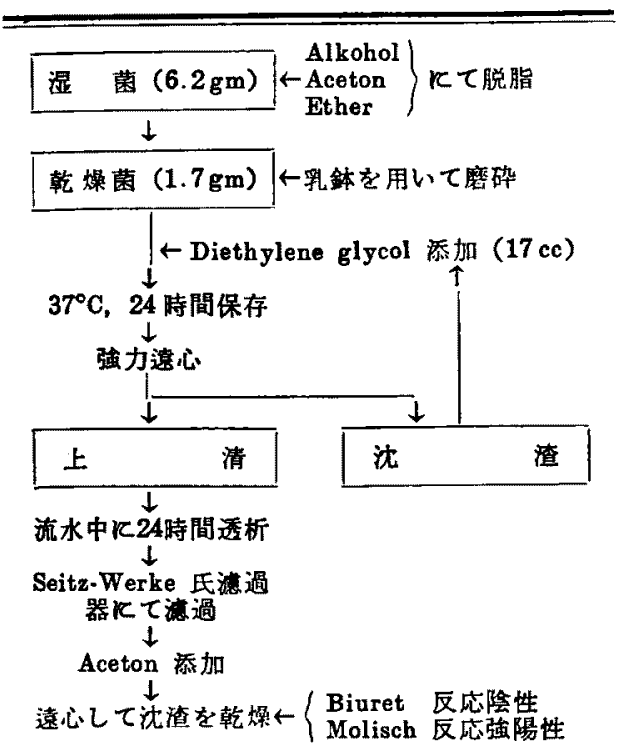

X19 菌を前述の如く培養し，集菌，脱脂した。 (脱脂湿菌 $6.2 \mathrm{gm}$ )この脱脂菌塊を自然乾燥せ しめて得た乾燥菌1.7 gmを乳鉢を用いて磨碎， 粉末状となし，これ《 $17 \mathrm{cc} の$ Diethylene glycol を添加して䜿濁液を作つた。 この䀣濁

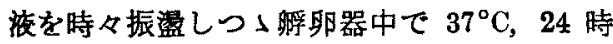
間抽出操作を行つた後，強力遠心し，その上 清を天然膀胱膜を用いて，流水中飞 24 時間 透析した。（沈渣飞は再び Diethylene glycol $17 \mathrm{cc}$ を加充，第 2 回抽出を同㥞飞行 5.) 透 ・析後, S氏㴧過器で清過し，この滤液に Aceton を加え，白色沈渐を生ぜしめ，これを集めて 減圧乾燥し保存した。

この様にして本菌塊に对し 5 回連続抽出を 行つた。

第了項 Trypsin に上る消化，並びに 精製法

Trypsin Kよる Proteus X19 菌の消化は, 第3 表代示す如く, Topley37)3B) 等, Wilson 33)37) 等, 及び Freeman ${ }^{33) 35339)}$ 等の方法飞涑 じて行つた，即ち，前述の如く培善，藮し 脱脂した Proteus X19 菌の脱脂湿菌塊 $1.8 \mathrm{gm}$ 飞対して，蒸溜水 $360 \mathrm{ccc}$, Toluol 18cc, N-NaOH 溶液 $0.81 \mathrm{cc}$ を加え（帮 8.2〜8.5）次て
第 3 表 Proteus X19 菌多糖類の Trypsin と上る消化順序

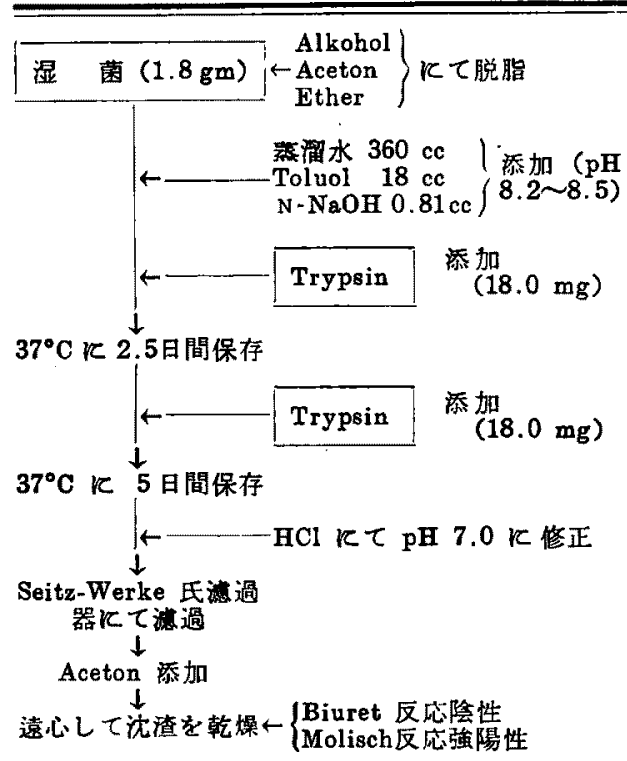

$18.0 \mathrm{mg}$ の Trypsin 末 (Merck 製) を加え て, 孵邲器中で 2.5 日間 $37^{\circ} \mathrm{C}$ 亿保存した後 再び Trypsin 末 $18.0 \mathrm{mg}$ を加えて，同栚瞬 卵器中で 5 日間保存した。 その後これを塩酸 を用いて $\mathrm{pH} 7.0$ 亿修正した後，精製の目的

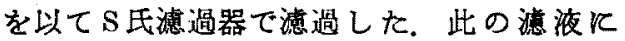
Acetonを加えて生じた白色沈激を遠心して集 め，減压乾燥して保存した。

第 2 節 家鬼の免度

前記 Proteus X19 菌を試験管普通寒天斜面 培美基に $37^{\circ} \mathrm{C}, 24$ 時間培養し，その 1 斜面 を $10 \mathrm{cc}$ の生理的食塩水汇浮游せしめ，乙れ を重湯前中で $60^{\circ} \mathrm{C} ， 2$ 時間，加温殺菌し， これを前記家兔の耳静脈内に 1 週間 2 回の間 隔で，第 1 回 $1 \mathrm{cc}$ ，第 2 回 $2 \mathrm{cc}$ ，第 3 回 $3 \mathrm{cc}$, 以後 $3 c c$ 宛注射した ${ }^{50)}$. 第 16 回注射後 8 日目 飞全採血を行い，抗 Proteus X19 菌免疫家 鬼血清を得た，之に防磨のため，100倍 Merthiolate を血清の $1 / 100$ 容量加兄て保存した。

第 3 節 Paper-Chromatography 本章第 1 節第 1 項に於て述べた三塩化醋酸

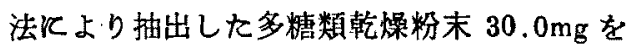
塩酸て玑水分解した後，送風乾燥して塩酸を 除き，これを Butanol, 水醌酸, 蒸溜水を 4： 
1：5の割合飞混合せる展開剂を用いて東洋港 紙 No. 50 亿展開した。

Spotの検出にはアンモニヤ硝酸銀法，及び 過マンガン酸加里法の 2 法を用いだ1;52)

第 4 節 Agar-Method

前節同様，三塩化醋酸法により抽出した多 糖類を抗原とし，本章第 2 節に於て述へた家 鬼血清を抗体として，Oudin ${ }^{53)}$ の方法に準じ て沈降反応を行つた.

即ち，生理的食塩水に1096の割合で精製寒

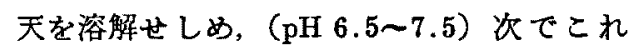
を熱い液状のま $\$ 4,000$ 回䢂で 15 分遠心して, 沈澱した夾雑物を切離し，上層の透明なる部 分のみを使用した。 この寒天を再び加熱溶解 して生理的食塭水で196亿稀秎し，これを以 $\tau$, 内径 $3 \mathrm{~mm}$ の沈降管の内壁を被脱した. 次に，この寒天を再び生理的食坫水で $0.6 \%$ の寒天尘理的食塭水液浠积し，1/500容量の Merthiolate を含有せしめ, 更に $48 \sim 50^{\circ} \mathrm{C}$ 飞 於て同温度の抗血清と同量混合した。これを 既飞被膜せる沈降管の $1 / 2$ 2/3 まで盛り， 10 15分間水室で寒天を凝固せしめた，次で 本菌多糖類を生理的食塩水て1：1,000亿稀釈 し, (1/10,000 容量の Merthiolate を含む)こ れを前述の抗血清寒天の上飞重㽪し，その反 応輸の移動距離を測定した。

測定は第 1 週の間は每日，第 2 〜第 3 遇は 隔日に行つた。

\section{第 5 節 $\mathrm{P}^{32}$ の導入}

Proteus X19 菌を Bouillon 中で 24 時間培 養した後，これに橉酸楥衝液を加克ると共に。 $\mathrm{P}^{32}$ を 60 万 Count 投入して, 再び瞹卵器中 K $37^{\circ} \mathrm{C}, 2$ 時間保存した後菓菌した。 然し て，この湿菌より前述せる三塭化醋酸抽出法 を用いて多糖類を抽出し，その多粘類と，多 糖類抽出後の残渣との各 Countを GeigerMüller 部数管を用いて检定した。 64)-67)

㭘定飞当り $\mathrm{P}^{32}$ 原液の $1: 10,000$ 生理的食 塩水溶液を対照として用いた。

第 6 節 菌体蛋白の滤紙電気泳動

本章第 1 節飞於て述へた如く Proteus X19 菌を培意後，これを集菌，脱脂，乾燥せしぬ
て得た乾燥菌塊飞 $\mathrm{N} / 100-\mathrm{NaOH}$ 溶液を加兄 て乳鉢で磨砕した，次で，之を遠心してその 上清を七ロファン膜を用い流水中に24時間透 析した．透析後，てれを送風乾燥し，再び生 理的塩食水汇溶解せしぬたるのを以て，滤紙 電気泳動法飞より東洋㵂紙 No. 51 を用いて 泳動を行つた ${ }^{58)-60)}$.

対照として同時に正常人血清の泳動を行つ た.

第 7 節 Proteus X19 菌多糖類の家 鬼抗血清に対する沈降反応

本章第 1 節策 1 項飞於て述へた三嗑化醋酸 抽出法により抽出した多糖類を抗原とし，本 章第 2 節に於て述へた抗 Proteus X19 菌家鬼 血清を抗体として，抗原抗体稀釈法61) とよる 沈降反応を行つた．抗原対照として生理的食 塩水を，抗体対照として正常家鬼血清を使用 した.

又，本章第 1 節に於て述べた各抽出（消化） 法の各過程 (11) 透析後或は消化後, (2) 滤過 後，(3)精製粉末）の溶液を抗原とし，本免疫 血清を抗体として，Uhlenhuth 氏法62) Kよる る沈降反応を行つた，然して各抽出法によつ て得た多糖類及び各抽出過程に於ける多糖類 の抗原としての活性物質の收量差並びに純度 を，Uhlenhuth 氏価を以て比較した。

沈降反忘の判定は，抗原を抗体に重層して 後，接触面に白輪を生じたるのを反応陽性と し，判定の表示は，重層後15分で陽性なる場 合H, 30分H，1時間H，2時間十とし，陰 性なる場合一とした。

\section{第 4 章 実跧成績}

\section{第 1 節 Proteus X19 菌多糖類の 化学的性状}

第 1 項 Biuret 反応及び Molisch 反応 前章第 1 節飞於て述へた各抽出法飞依つて 得た白色の乾燥粉末に就いて行つた Biuret 反応は陰性, Molisch 反応は強陽性であつた。

第 2 項 Paper-Chromatography 本多糖類を加水分解した後行つた PaperChromatography では，第 4 四飞示す如く， 
アンモニヤ硝酸銀 法に依る検出で，

3 筒の Spot る检 出した。

然して, 其の Spot の Rfは0.47,

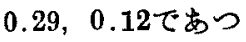
た.

又過マンガン酸 加里法による検出 に於てす同様の Spotを検出した。

第了項 Agar-

Method

Agar-Method $V$

よる沈降反応は,

第5図 a）及びb)

に示す如く，其の

反応輪恪終峃一

であつた。

又, この反応輸

の移動住， 1 週閪

で $2 \mathrm{~mm}, 2$ 週間

$3.5 \mathrm{~mm}, 3$ 週間 4

$\mathrm{mm}$ を示した。

第 4 項 $\mathrm{P}^{32}$ の導入

$\mathrm{P}^{32}$ を導入せる Proteus X19 菌多糖類の 收量は湿䒩 $1.0 \mathrm{gm}$ 飞対して $2.8 \mathrm{mg}$ であつ た。

然して，本多糖類と三塩化醋酸抽出残渣と の Count の比は以下の如くであつた.
(1) 多糖類 $(2.8 \mathrm{mg})$

51 Count

(2) 残渣 $(0.75 \mathrm{mg})$

33 Count

(3) 対照

164 Count

自然計数

23 Count

（但し，(1) (2) (3)の Count 数は自然計数を 含む)

即ち, 本多糖類 (Boivin type antigen) と

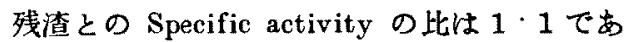
st.

第 5 項 菌件蛋白の潧紙電気泳動

第 6 図に示す如く，Proteus X19 菌蛋白の 滤紙電気泳動では，同時飞泳動した対照人血 清に対して，以下の如き 4 檑の蛋白質を認め た.

(1) Alb， $\alpha$-glob，中間位蛋白質

(2) $\beta$-glob，位蛋白質

(3) $r$-glob，位蛋白質

(4) $\gamma$-glob，原点位蛋白質

又，各々の菌体蛋白飞対する百分比は，(1) $29 \%$ ，(2) $36 \%$ （3） $14 \% ，(4) 21 \%$ あつた.

第 2 節 三塩化醋酸抽出法により抽出 した多糖類の抗 Proteus X19 菌家冤血清飞対する沈降反心

第 7 表俰示す如く，本反応に於ては，抗原 価 $1: 25,000$, 抗作価 $1: 50$, 結合带抗原価 $1 \cdot 5,000$ であつた。

第3 節 Proteus X19 菌多糖類の抽 出並び消化成績

第1 項 三塩化醋酸に上る抽出成績

第 3 章第 1 節第 1 項に於て述へた如く，同

笨 5 図 Agar-Method

a) 反応輸移動曲線

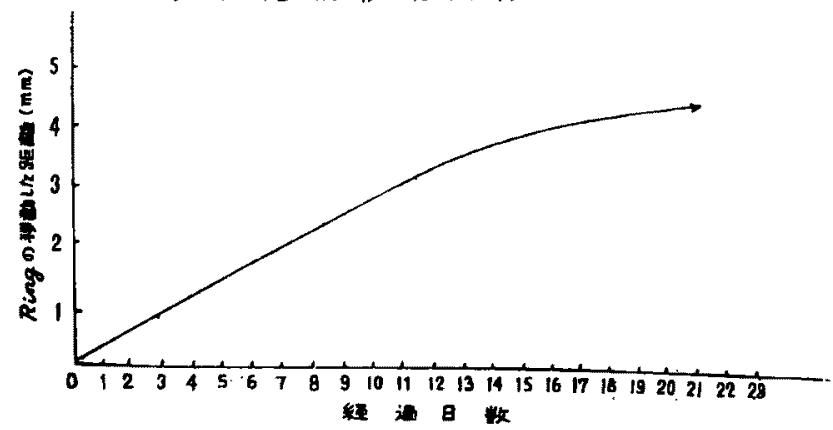

b) 反応図

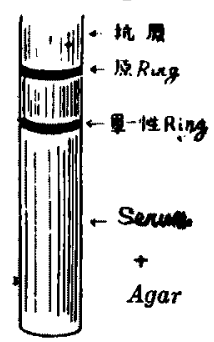


第 6 図菌体蛋白の滤紙電気泳動
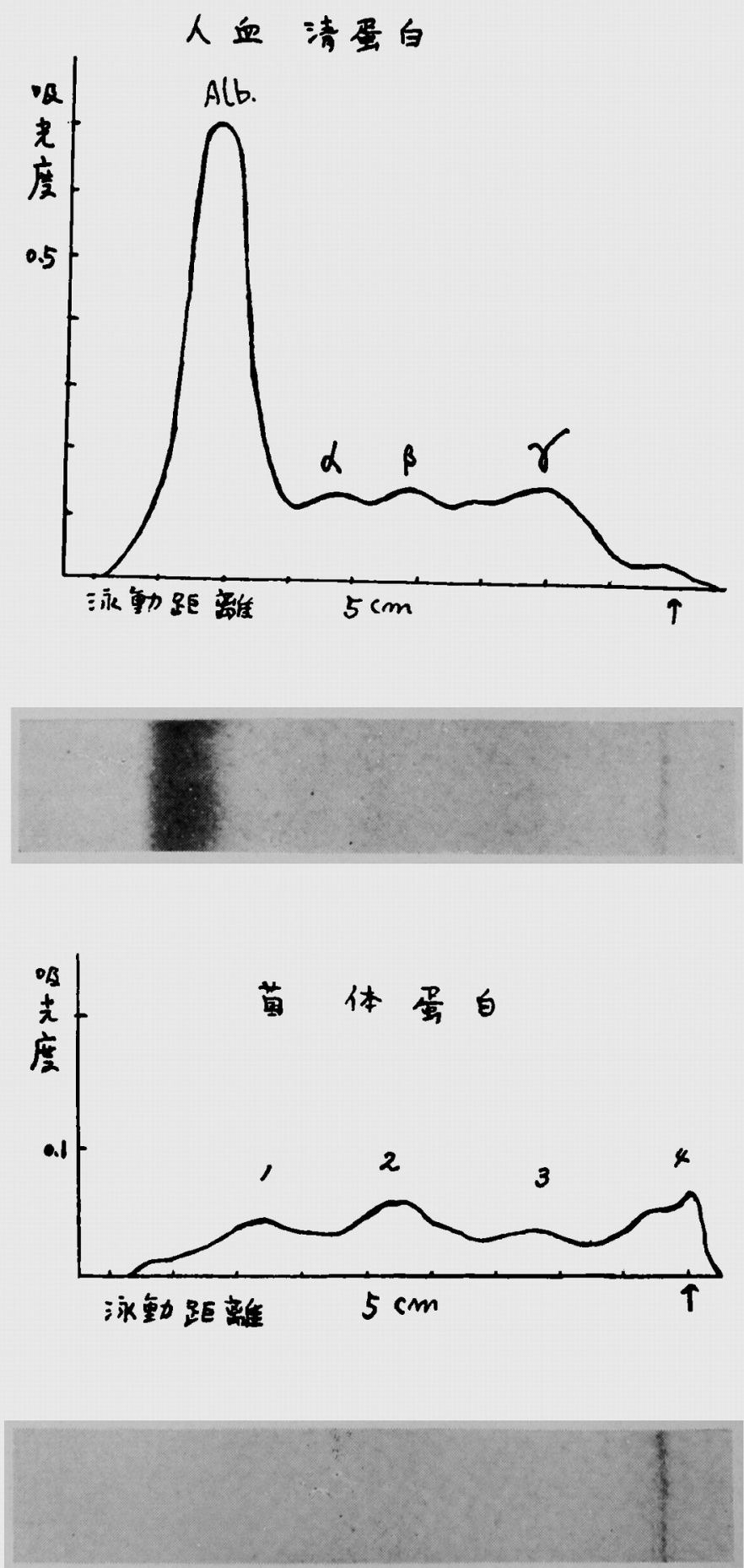
第 7 表 沈 降 反 応 Proteus X19 菌多糖類↔抗 ProteusX 19 家鬼血清系

\begin{tabular}{|c|c|c|c|c|c|}
\hline 抗原稀积度 & $\ddot{\ddot{n}}$ & $\begin{array}{l}0 \\
\because \\
-\end{array}$ & $\begin{array}{l}\text { ని } \\
\because \\
\rightarrow\end{array}$ & $\begin{array}{l}\text { 足 } \\
: \\
-1\end{array}$ & $\begin{array}{l}8 \\
\ddot{7} \\
-1\end{array}$ \\
\hline 1. 1,000 & H & HW & $H H$ & HW & - \\
\hline 1. 2,500 & HI & WI & $\mathrm{HH}$ & HW & - \\
\hline 1. 5,000 & Hitt & HH & $H$ & $\mathrm{H}$ & - \\
\hline $1: 10,000$ & $\mathrm{HH}$ & $\mathrm{HH}$ & 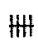 & $H$ & - \\
\hline $1: 25,000$ & Hit & HH & H & 'H & - \\
\hline $1: 50,000$ & - & - & - & - & - \\
\hline
\end{tabular}

一の脱脂後の湿菌塊 $2.0 \mathrm{gm}$ 対して，5回 連続して行つて抽出精製した多糖類の総收量 は $6.9 \mathrm{mg}$ であつた，然して，抽出精製過程 飞於ける溶液の家禹抗血清飞対する抗原価 (Ublenhuth 氏洒) 第 8 表深す如く,

$\begin{array}{ll}\text { 透析徭 } & 1: 25 \\ \text { 洏過後 } & 1: 10\end{array}$

乾燥粉末を滤過後液量の $1 / 10$ 量 の生理的食塩水飞溶解した場合 $1: 10$ であつた

然して，第]2表AK示す如く，抽出精製過

第 8 表 三塩化醋酸抽出法飞依る抽出成績 湿菌重 $2.0 \mathrm{gm}$

\begin{tabular}{|c|c|c|c|c|c|c|c|c|c|c|c|c|c|c|c|c|c|c|}
\hline \multirow{2}{*}{$\begin{array}{l}\text { 抽 } \\
\text { 出 } \\
\text { 回 } \\
\text { 数 }\end{array}$} & \multirow{2}{*}{$\begin{array}{c}\text { 三酸 } \\
\text { 塩添 } \\
\text { 化加 } \\
\text { 醋量 } \\
\text { cc }\end{array}$} & \multirow{2}{*}{$\begin{array}{l}\text { 抽 } \\
\text { 出 } \\
\text { 液 } \\
\text { 量 } \\
\text { cc }\end{array}$} & \multirow{2}{*}{$\begin{array}{l}\text { 透 } \\
\text { 析 } \\
\text { 後 } \\
\text { 液 } \\
\text { 量 } \\
\text { cc }\end{array}$} & \multirow{2}{*}{$\begin{array}{l}\text { 洃 } \\
\text { 過 } \\
\text { 後 } \\
\text { 液 } \\
\text { 量 } \\
\text { cc }\end{array}$} & \multirow{2}{*}{$\begin{array}{c}\text { 幹 } \\
\text { 焒 } \\
\text { 粉 } \\
\text { 末 } \\
\text { 量 } \\
\text { mg }\end{array}$} & \multicolumn{4}{|c|}{$\begin{array}{l}\text { 透析後液 } \\
\text { 抗 原 価 }\end{array}$} & \multicolumn{6}{|c|}{ 滤過後液の抗原価 } & \multicolumn{3}{|c|}{ 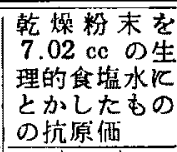 } \\
\hline & & & & & & 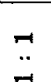 & 은 & $\stackrel{4}{\mathrm{~N}}$ & 8 & $\rightarrow$ & 윽 & ลัง & 요 & $\stackrel{8}{\circ}$ & 웅 & - & $\begin{array}{l}0 \\
\because \\
-1\end{array}$ & \\
\hline 1 & 10 & 7.8 & 7.8 & 5.5 & 2.0 & 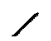 & 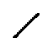 & r & 1 & 曲 & H\# & $\mathrm{WH}$ & & + & - & / & / & \\
\hline 2 & 10 & 10.0 & 14.0 & 11.6 & 2. & I & $\gamma$ & I & I & 冊 & HW & HI & \# & + & - & ノ & I & \\
\hline 3 & 10 & 9.8 & 25.0 & 23.4 & 1.75 & $\gamma$ & $\gamma$ & 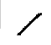 & 1 & H & HWI & H & + & - & - & ノ & 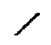 & \\
\hline 4 & 10 & 10.0 & 11.6 & 9.6 & 0.25 & 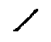 & $\gamma$ & ' & ノ & HW & \# & - & - & - & - & 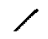 & $\zeta$ & \\
\hline 5 & 10 & 9.4 & 42.0 & 40.1 & 0.85 & $\gamma$ & ' & $\gamma$ & 1 & HW & - & - & - & - & - & ノ & $\%$ & ノ \\
\hline 計 & 50 & 7.0 & 0.4 & .2 & 6.9 & $\mathrm{HW}$ & $\mathrm{mtt}$ & HEt & - & If & Ht & - & & - & - & $\pi$ & $H$ & \\
\hline
\end{tabular}

程に於ける抗原としての活性物質の收量差を 乾燥粉末を 1 として，透析後液及び㥁液に就 いて比較した場合は，以下の如くであつた， 即ち 透析後：㥁液：粉末 $=36: 10: 1$

（但し，Uhlenhuth 氏価と液量の積を以て 算出)

又，第 8 表《示す如く，抽出回数の進むに つれて抽出收量が減少しているのであるが， 第 1 回抽出と第 2 回抽出とが殆ど差が無く， むしろ，第 2 回抽出飞於て強い沈降反応が認 められたのは，第 1 回抽出の際には菌体の破 壊が末だ不充分で，満足すへき抽出作用が行 われなかつた為であるらと考えられる。

第2 項 Diethylene glycol 飞よる抽出 成績

第 3 章第 1 節第 2 項に於て述べた如く，同 一乾燥菌 $1.7 \mathrm{gm}$ (湿菌量6.2 gm) 飞対して5
回連続して行つて抽出精製した多糖類の総收

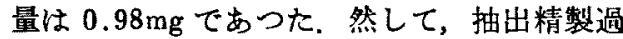
程に於ける溶液の家㭸抗血清飞対する抗原価 （Uhlenhuth 氏価）は，第 9 表に示す如く，

$\begin{array}{ll}\text { 透析後 } & 1: 10 \\ \text { 滤過後 } & 1: 1\end{array}$

乾燥粉末惯過後液量の $1 / 10$ 量 の生理的食塩水飞溶解した場合 $1: 1$

であつた。

然して，第12表A K示す如く，抽出精製過 程に於ける抗原としての活性物質の收量差を， 乾燥粉末を 1 として，透析後液及び港液に就 いて比較した場合は以下の如くであつた。

即ち，透析後：滤夜：粉末 $=108: 10: 1$

又, 本抽出法飞於ては, 第 9 表飞示可如く， 第 1 回抽出飞於て，や」強い抗原価を示し，

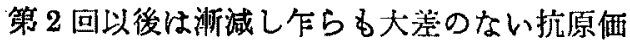


第 9 表 Diethylene glycol 抽出法に上る抽出成縝

湿菌重量 $6.2 \mathrm{gm}$ (乾燥菌 $1.7 \mathrm{gm}$ )

\begin{tabular}{|c|c|c|c|c|c|c|c|c|c|c|c|c|c|c|}
\hline \multirow{2}{*}{$\begin{array}{l}\text { 抽 } \\
\text { 出 } \\
\text { 回 } \\
\text { 数 }\end{array}$} & \multirow{2}{*}{ 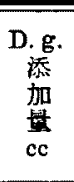 } & \multirow{2}{*}{$\begin{array}{l}\text { 抽 } \\
\text { 出 } \\
\text { 㖡 } \\
\text { cc } \\
\text { cc }\end{array}$} & \multirow{2}{*}{$\begin{array}{l}\text { 透液 } \\
\text { 析 } \\
\text { 後量 } \\
\text { cc }\end{array}$} & \multirow{2}{*}{$\begin{array}{l}\text { 渍液 } \\
\text { 過 } \\
\text { 後量 } \\
\text { cc }\end{array}$} & \multirow{2}{*}{$\begin{array}{r}\text { 乾枌 } \\
\text { 末 } \\
\text { 燥量 } \\
\mathbf{m g}\end{array}$} & \multicolumn{3}{|c|}{ 透析後液の抗原価 } & \multicolumn{3}{|c|}{ 滤過後波の抗原価 } & \multicolumn{3}{|c|}{ 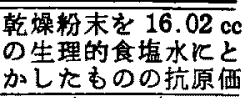 } \\
\hline & & & & & & $\ddot{\ddot{\theta}}$ & 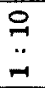 & $\begin{array}{l}\stackrel{\mathscr{N}}{\mathrm{N}} \\
\because \\
-\end{array}$ & $\ddot{7}$ & $\begin{array}{l}\text { 음 } \\
\ddot{-}\end{array}$ & $\begin{array}{l}\stackrel{4}{0} \\
\because \\
-\end{array}$ & 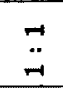 & $\begin{array}{l}\stackrel{9}{-} \\
\ddot{-1}\end{array}$ & 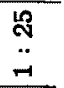 \\
\hline 1 & 17 & 10.0 & 21.0 & 17.4 & 0.15 & $\nearrow$ & 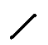 & $\gamma$ & H & + & - & ノ & $\nearrow$ & ノ \\
\hline 2 & 17 & 10.0 & 33.4 & 30.6 & 0.15 & $\gamma$ & 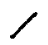 & ノ & H & - & - & $\nearrow$ & $\gamma$ & ノ \\
\hline 3 & 17 & 15.4 & 26.0 & 23.4 & 0.2 & $\nearrow$ & $\nearrow$ & $ノ$ & H & - & - & ノ & 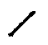 & ノ \\
\hline 4 & 17 & 14.6 & 52.9 & 49.2 & 0.23 & ノ & $\gamma$ & I & \# & - & - & ノ & ノ & $\nearrow$ \\
\hline 5 & 17 & 14.0 & 42.7 & 40.6 & 0.25 & Y & r & $\nearrow$ & $H$ & - & - & I & $\nearrow$ & $\nearrow$ \\
\hline 合 計 & 85 & 64.0 & 176.0 & 160.2 & 0.98 & 曲 & + & - & 册 & - & - & 世 & - & - \\
\hline
\end{tabular}

を示した。

第3 項 Trypsin 飞よる消化成績

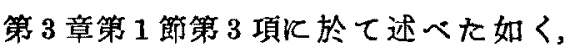
Trypsin とよる消化は 8 日間行つた. 然して 精製粉末の総量は湿菌1.7gm飞対して40.0 m であつた，又，消化精製過程に於ける溶液の 家兔抗血清江対する抗原価 (Uhlenhuth 氏価) は第10表《示す如く，

消化後

$1: 25$

溓過後

\section{乾燥粉末を滤過後㴕量の $1 / 20$ 量 $1: 1$ の生理的食塩水飞溶解した場合 $1:$} であつた。

然乙て第12表A K示す如く，消化精製過程 飞於ける抗原としての活性物質の收量差を, 乾燥粉末を 1 として，消化後溶液及び滤液飞 就いて此較した場合は以下の如くであつた。

即ち, 消化後: 滤過後・粉末 $=570: 20: 1$ 又，消化経過中反於ける消化の進行状態を 抗血清に対する沈降反心飞依つて検討した結

第 10 表 Trypsin 消化法飞よる消化成樍 湿菌重显 $1.8 \mathrm{gr}$

\begin{tabular}{|c|c|c|c|c|c|c|c|c|c|c|c|c|c|c|c|c|}
\hline \multirow{2}{*}{$\begin{array}{c}\text { 消 } \\
\text { 化 } \\
\text { 日 } \\
\text { 数 }\end{array}$} & \multirow{2}{*}{$\begin{array}{c}\text { 添加液 量 } \\
\text { cc }\end{array}$} & \multirow{2}{*}{$\begin{array}{cc}\text { 消 } & \text { 化 } \\
\text { 後湤量 } \\
\text { cc }\end{array}$} & \multirow{2}{*}{ 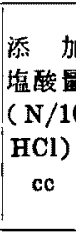 } & \multirow{2}{*}{$\begin{array}{c}\mathrm{HCl} k \tau \\
\text { pH7.0 } \\
\text { 修正後の } \\
\text { 腋量 } \\
\text { cc }\end{array}$} & \multirow{2}{*}{$\begin{array}{l}\text { 湴 } \\
\text { 過 } \\
\text { 後 } \\
\text { 液 } \\
\text { 量 } \\
\text { cc }\end{array}$} & \multirow{2}{*}{$\begin{array}{l}\text { 乾 } \\
\text { 嬠 } \\
\text { 粉 } \\
\text { 束 } \\
\text { 意 } \\
\text { mg }\end{array}$} & \multicolumn{4}{|c|}{ 液過前の抗原価 } & \multicolumn{3}{|c|}{$\begin{array}{l}\text { 㴁過 後の } \\
\text { 抗 原 価 }\end{array}$} & \multicolumn{3}{|c|}{ 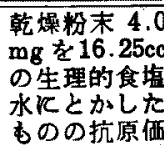 } \\
\hline & & & & & & & 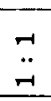 & $\begin{array}{l}\circ \\
\stackrel{-}{-} \\
-\end{array}$ & $\begin{array}{l}\mathscr{2} \\
\ddot{-}\end{array}$ & $\mid \begin{array}{l}0 . \\
. \ddot{-} \\
-7\end{array}$ & $\overrightarrow{\ddot{H}}$ & $\begin{array}{l}0 \\
\stackrel{2}{-} \\
\sim\end{array}$ & $\begin{array}{l}\text { 足 } \\
\stackrel{-}{-}\end{array}$ & $\begin{array}{ll}-1 \\
-1\end{array}$ & $\stackrel{\circ}{\because}$ & $\begin{array}{l}\stackrel{3}{*} \\
\ddot{-} \\
\end{array}$ \\
\hline 8 & $\begin{array}{l}\text { 敏水 } 360 \\
\text { Toluol } 18 \\
\mathrm{~N}-\mathrm{NaOH} \\
0.81\end{array}$ & 365 & 1 & 366 & 325 & 40.0 & HW & HW & $H$ & - & $H H$ & - & - & $1+$ & - & - \\
\hline
\end{tabular}

第11図 Trypsin 消化法の消化経過時間及び 日数に於ける抗原伍の経過曲線

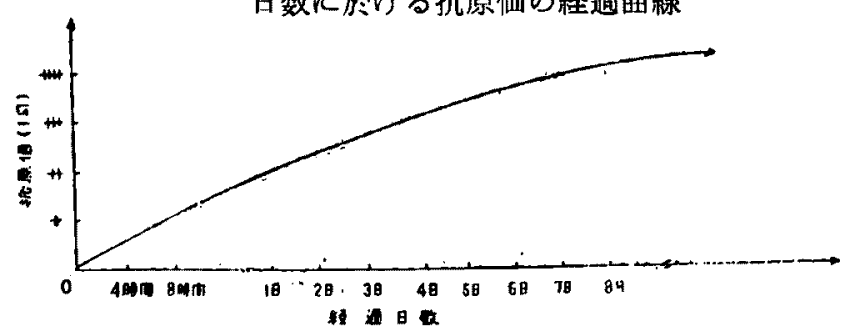

果は，第11図に示す如くであつ た.

即ち，消化 4 時間まで 一

$\begin{array}{ll}\text { " } 8 \text { 時間 } & + \\ \text { " } 24 \text { 時間 } & \text { H } \\ \text { " } 48 \text { 時間 } & \text { H } \\ \text { " } 4 \text { 日 } & \text { H } \\ \text { " } 8 \text { 日 } & \text { H }\end{array}$


であつた。

第 4 項 各抽出（或は消化）法飞より得 たる多糖類の收量及び純度比

各抽出（或は消化）法相互間の抗原として の活性物質の收量比は，第12表 BK示す如く， Diethylene glycol 法を1.として,

三塩化醋酸法: Diethylene glycol 法.

Trypsin 法=13:1:3

又, 純度比は Trypsin 法を 1 として,

三塩化醋酸法 : Diethylene glycol 法:

Trypsin 法=2:3.5:1

であつた。

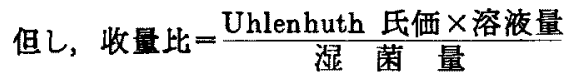
䄴度比 $=\frac{\text { Uhlenhuth 氏価 } \times \text { 容液量 }}{\text { 精製乾燥粉末 }}$

第12表 A 各抽出（消化）法飞於ける透 析（消化）滤過及び乾燥の收 量比

\begin{tabular}{|c|c|c|c|}
\hline 方法 & $\begin{array}{l}\text { 毐告化醋 } \\
\text { 酸抽出法 }\end{array}$ & $\begin{array}{l}\text { Diethyl. } \\
\text { gl. 抽出法 }\end{array}$ & $\begin{array}{l}\text { Trypsin } \\
\text { 消化法 }\end{array}$ \\
\hline 收 & 13 & 1 & 3 \\
\hline 度 & 2 & 3.5 & 1 \\
\hline
\end{tabular}

第12表 B 各抽出（消化）法飞依り抽出 せる多糖類の收量及び純度比

\begin{tabular}{|c|c|c|c|}
\hline 法 & $\begin{array}{l}\text { (透析後後) } \\
\text { (消化 }\end{array}$ & 洪過後 & 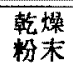 \\
\hline 三塻化醋酸抽出法 & 36 & 10 & 1 \\
\hline Diethylene glyc. 抽出法 & 108 & 10 & 1 \\
\hline Trypsin 消 化 & 570 & 20 & 1 \\
\hline
\end{tabular}

\section{第 5 章 考按}

Proteus X19 菌多糖類の分離精整法とし $\tau$, 三塩化醋酸法, Diethylene glycol 法, 及 ぴ Trypsin 法を行つたが，前 2 法では 5 回連 繶抽出を行つて, 其の総收量を求めた。 然し て，これら抽出に際しては全般的に抽出回数 が進むにつれて，其の收量が減ずる傾向にあ る. 但し, 三塩化醋酸法泛於て, 第 1 回抽出 の收量よりる第 2 回が多くなつてをり，又， 抗血清注対寸る沈降反心がや」強く現われて いるのは, 第 1 回抽出浪て於て菌体の破壤が
な性充分でなかつた事依るすと考光られ るが、第 4 回上り第 5 回が多くなつているの は，抗血清飞対する両者の抗原価より考えて 奏験上の誤差であるう。

又, Diethylene glycol 法では全般的に收量 が悪く、第 2 回抽出以後の沈降反応抗原価飞 大差が認められなかつた。 且つ Diethylene glycol は甚しく粘稠である為飞，遠心分離が 不完全になり易く，従つて抽出誤差す多かつ た事と考えられる.

又，各抽出（消化）法による多糖類收量は (1) 三塩化醋酸法 (2) Trypsin 法 (3) Diethylene glycol 法の順であり，純度は (1) Diethylene glycol 法 (2) 三塩化醋酸法 (3) Trypsin 法の 順であって，三塩化醋酸法は收量及び純度共 優秀であつて且つ抽出操作が比較的簡易な方 法であると思われる．然して，Bendich47) 等 も三塩化醋酸法と Trypsin 法とを比較して前 者の秀れている事を述べている。

一般に，多糖類分離法の優少は，其の操作， 收量及び純度によつて此較せらるべきであつ て,この三塩化醋酸法に比すれば, Castaneda 43)44) の Antiformin 法は純度飞於て，黑屋 48) 等の中性及び酸性加熱法は操作の複雑さに於 て，や小劣るものがあるのではないかと思わ れる.

又，先に述へた如く，多糖類分離に当つて は，強酸，アルカリ，及び加熱処理は，其の 抗原性に変化を与える捂それがある為化可及 的行わぬのが良いのではあるまいか.

\section{第 6 章 結論}

Proteus X19 菌より，三塩化醋酸法， Diethylene glycol 法, 及び Trypsin 消化法 で多糖類を分離精製して，其の收量及び純度 を比挍した結果, 次の如き成緗を得た。

（1）收量に於ては，三塩化醋酸法>Trypsin 法>Diethylene glycol 法の順である.

（2）純度飞於ては，Diethylene glycol 法> 三塩化醌酸法>Trypsin 法の順である。

(3) 抽出（消化）後の多糖類柱 S 氏滤墖器 による精製のために 1/3.6 1/28.5 K減し，乾 
燥粉末では更に $1 / 10$ １/20 K減ずる.

（4）本多糖類は長期保存が可能である.

（5）三塩化醋酸法により抽出した多糖類に 就いて，その化学的性状を検定した結果，

Paper-Chromatography で水解後 3 簓の糖類 と思われる Spot を得た。

・(6) Agar-Method で単一抗原なる事を認 めた.

\section{主 要 文 献}

1) Toenniessen: Ztb. Bact. Orig., 85, 225, 1920.

2) Landsteiner-Levine: J. Exp. Med., 46, 213, 1927.

3) Landsteiner et al.: J. Exp. Med., 52, 347, 1930.

4) Landsteiner et al. . J. Exp. Med., 57, 633, 1933.

5) Landsteiner et al. J. Exp. Med., 64, 625, 1936.

6) Avery-Goebel : J. Exp. Med., 58, 731, 1933.

7) Avery Tillet · J. Exp. Med., 49, 251, 1929.

8) Heidelberger-Avery: J. Exp. Med., 38, 73, 1923.

9) Heidelberger-Avery: J. Exp. Med., 40, 301, 1924.

10) Heidelberger-Avery: J. Exp. Med., 42, 701, 1925.

11) Heidelberger-Avery: J. Exp. Med., 42, 72, 1925.

12) Heidelberger-Avery: J. Exp. Med, 64, 559, 1936.

13) Heidel berger-Avery: J. Exp. Med., 49, 847, 1929.

14) Heidelberger-Kendal : J. Biol. Chem., 96, 541, 1932.

15) Heidelberger-Kendal : J. Exp. Med., 55, $555,1932$.

16) Heidelberger-Kendal: J. Exp. Med., 53, 625, 1931.

17) Heidelberger-Menzel: Proc. Soc. Exp. Biol. \& Med., 29, 631, 1932.

18) Heidelberger-Goebel ; J. Biol. Chem., 74. $613,1927$.

19) Goebel: J. Exp. Med., 62, 179, 1935.
(7) Boivin type antigen $K \mathrm{P}^{32}$ の導入を 認めた。

稿を終るに当り，釉始御想篤なる御指运と御校閲 を賜つた恩師大田原教授汇深謝すると共に，種々御 助言を戴いた楮方助敦授飞謝意を捧げる。

（本論文の要旨は昭和30年11月第65回岡山医学䌊 会，及び昭和 31 年 4 月第 26 回日本衛生学会総会飞於 て発表した.)

20) Goebel-Avery-Baber : J. Exp. Med., 50, 521, 1929.

21) Goebel-Avery-Baber: J. Exp. Med., 54, 437, 1931.

22) Goebel-Avery-Baber: J. Exp. Med., 55, 761, 1932.

3) Goebel-Avery-Baber: J. Exp. Med., 60, 85, 1934.

24) Goebel-Hotchkis : J. Biol. Chem., 115, 285, 1936.

25) Sevag et al. : Lieb. Ann. Chem., 519, 111, 1935.

26) Boivin, A. and Mesrobeanu, L.: Comp. Rendsoc. Biol., 113, 490, 1933.

27) Boivin, A. and Mesrobeanu, L.: Comp. Rendsoc. Biol., 114, 302, 307, 1933.

28) Boivin, A. and Mesrobeanu, L.: Rev. d. Immunol., 1, 553, 1935.

29) Boivin, A. and Mesrobeanu, L. : Rev. d. Immunol., 2, 113, 1936.

30) Boivin, A. and Mesrobeanu, L. : Rev. d. Immunol,, 3, 319, 1937.

31) Boivin, A. and Mesrobeanu, L. . Rev. d. Immunol., 4, 40, 197, 1938.

32) Boor, Ak. and Miller, C. P. . J. Infect. Dis., 35, 47, 1944.

33) Freeman, G. G., Challinor, S. W. and Wilson, J. : Biochem. J., 35, 307, 1940.

34) Morgan, W. T. J. and Partridge, S. M. : Biochem. J., 34, 169, 1940.

35) Freeman, G. G., Challinor, S. W. and Wilson, J.: Biochem. J., 34, 307, 1940.

36) Henderson, D.W. and Morgan, W. T.J.: Brit. J. Exp. path. 19, 82, 1938.

37) Topley, Raistrick, Wilson, Stacey, Challinor, 
Clark : Lancet., I, 252, 1937.

38) Raistrick, Topley: Brit. J. Exp. path., 15, 113, 1934.

39) Freeman, Challinor, Wilson: Biochem. J., 34, 307, 1940.

40) Przesmycki : C. R. Soc. Biol., 95, 744, 1926.

41) Meisel, Mikulaszek : C. R. Soc. Biol., 114, $361,364,1933$.

42) Zinsser, Castaneda : J. Exp. Med., 56, 455, 1932.

43) Castaneda, Zia: J. Exp. Med., 58, 55, 1933.

44) Castaneda: J. Exp. Med., 60,119, 1934.

45) Furth, Landsteiner: J. Exp. Med., 49, 727, 1929.

46) White : Brit. J. Exp. path., 14, 145, 1933.

47) Bendich, Chargaff: J. Biol. Chem., 168, 283, 1946.

48)黑屋，川上：血清学兔疫学雜誌，3(3) 377 , 昭17年。
49) 岡本, 吉沢:日本細菌学雑誌, I (2) 241, 昭 19年.

50) 須之内: 岡山医学会雑誌, 41 (1) 1, 昭 4 年,

51）化学の領域, $5,8,31$.

52）佐竹：クロマトグラフィー，共立全畵， 12 .

53) Oudin: J. Immunol., 65, 47, 1950.

54) Warren: Phytopath., 41, 794, 1951.

55) Clark and Goring: J. Bact., 62, 352, 1951.

56) 三好，金，伊藤：医学と生物学，39，9，1956.

57) 野中：Radioisotopes,, 4 (2) 37, 1956.

58) Grassmann, W. \& Hannig, K.: Naturwissenschaften, 37, 397, 1950.

59）小林：生物物理化学，2, No. 1，3，1954。

60) 小林，森：滤紙電気泳野法の実際，南江堂， 1955.

61) Ogata: Z. f. Immunität Forsch. Org. Bd. $39,270,1924$.

62) Uhlenhuth: Prkt. Anleit. Zur Ausführ. biol. Eiweissdiff. (Jena) 1909.

\title{
Studies on the Antigenicity of Bacterial Polysaccharides
}

Part 1:

\author{
On the Refining of B. Proteus X19 Polysaccharide
}

By

\section{Mamoru Yokoyama}

Department of Public Health Okayama University Medical School (Director: Prof. Dr. K. Ohtahara)

By using trichloracetate method, diethylene glycol method, and trypsin digestion method, the author has separated a polysaccharide from B. Proteus X19 and refined it, and then having compared the respective quantity and purity derived from each method, the following results have been obtained.

1) The quantity derived in each method has been found in the order of trichloracetate method $>$ trypsin method $>$ diethylene glycol mothod.

2) The comparison of the purity so determined has been found diethylene glycol method $>$ trichloracetate method $>$ trypsin method, in the order mentioned.

3) The quantity of polysaccharide after extraction (digestion) is reduced to $1 / 3.6-1 / 28.5$ on account of the refining by the Seitz.Werke filter. When dried and pulverized, it has been further reduced to $1 / 10-1 / 20$.

4) It is possible to preserve this polysaccharide for a long period of time.

5) Having examined the chemical nature of polysaccharide abstracted by trichloracetate mothod, and after hydrolysis with paper-chromatography, three saccharide-like spots have 
been obtained.

6) This polysaccharide has been recognized to be a monoantigen by agar - method.

7) The introduction of $P^{32}$ into Boivin type antigen has been ascertained. 